\title{
Brachial index does not reflect upper extremity functionality following surgery for vascular trauma
}

\author{
O índice tornozelo-braço não reflete a funcionalidade da extremidade \\ superior após cirurgia para o trauma vascular
}

Erdal Simsek', Kasim Karapinar², Ilker Ince³, Ahmet Tulga Ulus

\begin{abstract}
Objectives: Vascular injuries to the upper extremities requiring surgical repair are common after accidents. However, neither postoperative functionality nor hemodynamic status of the extremity are routinely described. We evaluated the postoperative functional and hemodynamic status of patients with vascular traumas in the upper extremities. Methods: 26 patients who suffered penetrating vascular traumas in the upper extremities from November 2008 to December 2011 were retrospectively evaluated. Data on first approach, surgical technique employed and early postoperative outcomes were recorded. Further data on the post-discharge period, including clinical functional status of the arm, Doppler ultrasonography and brachial-brachial index were also evaluated. Results: Average follow up was $33.5 \pm 10.8$ months. Right $(1.05 \pm 0.09)$ and left (1.04 \pm 0.08$)$ brachial indexes were measured during follow up,. Doppler ultrasonography showed arterial occlusion in 4 patients (15\%). Near-normal brachial-brachial indexes was observed in all four of these patients with occlusion of one of the upper extremity arteries, even though they exhibited limited arm function for daily work. Conclusions: Evaluation of the postoperative outcomes of this small series of patients with penetrating vascular traumas in the upper extremity revealed that $15 \%$ of them suffered occlusion of one artery of the upper extremity. Artery occlusion did not correlate with brachial-brachial Doppler index, probably due to rich collateral circulation, but occlusion was associated with an extremity that was dysfunctional for the purposes of daily work. The result of the brachial-brachial index does not therefore correlate with functionality.
\end{abstract}

Keywords: arterial injury; trauma; upper extremity; brachial-brachial index; multidisciplinary approach.

\begin{abstract}
Resumo
Objetivos: Os vasos das extremidades superiores são frequentemente lesados em razão de acidentes. Nós pesquisamos a funcionalidade dos membros superiores com base nos resultados cirúrgicos, além do acompanhamento de lesões de outros órgãos e tecidos. Métodos: Entre novembro de 2008 e dezembro de 2011, 26 pacientes foram encaminhados ao nosso serviço de emergência em razão de lesões vasculares traumáticas da extremidade superior, sendo avaliados retrospectivamente. $\mathrm{O}$ atendimento inicial aos pacientes, assim como os diagnósticos e as variedades de tratamento, foram avaliados. Após a alta hospitalar, os pacientes foram acompanhados pelo eco-Doppler e pelo índice tornozelobraço. Resultados: $O$ tempo médio de seguimento foi de 33,5 $\pm 10,8$ meses. Durante o seguimento, os índices braquiais direito $(1,05 \pm 0,09)$ e esquerdo $(1,04 \pm 0,08)$ foram medidos. Na ultrassonografia Doppler, foi observada obstrução arterial em quatro pacientes. Devido à circulação colateral, o índice tornozelo-braço foi próximo do normal nesses pacientes; entretanto, eles apresentavam limitações funcionais dos membros superiores acometidos, para o trabalho diário. Conclusões: Traumas penetrantes são frequentemente observados em adultos jovens. Esses pacientes devem ser rapidamente tratados para que retornem ao seu trabalho. O planejamento do tratamento deve ser multidisciplinar, para abranger também as lesões de outros órgãos e tecidos. Nosso estudo mostrou que não há correlação entre o índice tornozelo-braço e a funcionalidade da extremidade superior, após cirurgia para o trauma vascular.
\end{abstract}

Palavras-chave: lesão arterial; trauma; membro superior; índice tornozelo-braço; abordagem multidisciplinar.

\footnotetext{
Turkiye Yuksek Ihtisas Training and Research Hospital, Department of Cardiovascular Surgery, Ankara

Diskapi Yildirim Beyazit Training and Research Hospital, Department of Cardiovascular Surgery, Ankara

${ }^{3}$ Tokat Gaziosmanpaşa University, Department of Cardiovascular Surgery, Tokat

Financial support: None.

Conflicts of interest: No conflicts of interest declared concerning the publication of this article.

Submitted: 10.04.13. Accepted: 03.18.14
}

The study was carried out at two centers (Turkiye Yuksek Ihtisas Training and Research Hospital, Ankara and Diskapi Yildirim Beyazit Training and Research hospital, Ankara). 


\section{INTRODUCTION}

Traumas often lead to upper extremity injuries because of people's reflex to protect themselves. The brachial artery is one of the arteries most prone to injury from bone fragments, sharp and penetrating objects and blunt traumas. The frequency of vascular injury is higher in penetrating traumas compared to blunt injuries. ${ }^{1}$ Clavicle fractures are responsible for the $50 \%$ of subclavian arterial injuries. ${ }^{2}$ The incidence of vascular system damage is $48 \%$ in blunt thorax traumas. ${ }^{3}$ Vascular injuries can result from upper extremity traumas and in $28 \%$ of these the brachial artery is affected. ${ }^{4}$

Upper extremity vascular injuries are common in emergency rooms. The majority of them are immediately treated by vascular surgeons. The frequency of venous injuries is lower than arterial injuries. Nerve tissues runs parallel to the vascular system and as a result nerves are also at a high risk of injury.

Early transport of patients, early diagnosis and early surgical treatment have together contributed to increased postoperative success rates in recent years. However, it is important to determine, whether these injuries impact the capacity to work and cause motor deficit of the arm, in order to prescribe specialized treatment to avert major dysfunctionality. It is therefore important to follow-up these patients after surgery. Trauma patients are usually young active individuals and should be able to go back to work as soon as possible with effective treatment.

\section{METHODS}

Twenty-six patients who suffered upper extremity vascular traumas from November 2008 to December 2011 were evaluated retrospectively. This study was approved by internal review board at the hospital (No: 297; 07.01.2013).

Patients presenting at our center were operated according to certain principles. In accordance with the Advanced Trauma Life Support Guidelines, ${ }^{5}$ all patients with emergency upper extremity vascular traumas were evaluated with reference to presence of at least two of the following symptoms, accepted as a strong signs of arterial damage: inability to find a pulse or weak distal pulse, arterial bleeding, pulsatile hematoma, growing hematoma and/or presence of spreading thrill.

Tetanus vaccine and antibiotic prophylaxis were administered after stabilization of vital signs (blood transfusion, volume expanders). Temporary hemostasis was achieved by surgical intervention, compression or tourniquet of active bleeding.
Physical examination, Doppler ultrasonography (dUSG) and digital subtraction angiography (DSA) were available for all vascular trauma patients. However, patients with radial and ulnar arterial injuries were treated immediately after physical examination.

Patients with brachial artery, axillary artery and vein, jugular vein, basilar vein and subclavian vein injuries were diagnosed using dUSG.

Patients who had injured tissues other than vascular structures were operated by a multidisciplinary team. Local or general anesthesia were chosen depending on patients' status and the areas damaged. All vascular injuries were managed by vascular surgeons. During surgical repair, end to end anastomoses were conducted using one of two different sewing techniques depending on vascular diameter (single sewing technique for thin vessels and continuous sewing technique for larger vessels). Saphenous vein, polytetrafluoroethylene (PTFE) or Dacron grafts were used where end to end anastomosis was not possible. Simple vessel ligation was used in cases in which there was no chance of repairing radial and ulnar arterial injuries. For venous injuries, saphenous vein or PTFE grafts were used if primary repair could not be accomplished.

Upper extremity vascular trauma patients were evaluated in terms of injury features, surgical procedures performed and concomitant extravascular tissue injuries. Postoperatively, they were evaluated in terms of loss of capacity to work and functional status of the arm for daily work.

Length of hospital stay was recorded. Followups were conducted at intervals of 3 to 6 months with physical examination, dUSG and the brachialbrachial index (upper extremity systolic pressure ratio to the lower extremities). Depending on follow-up findings, patients with disabilities affecting physical activities were prescribed physical therapy and rehabilitation.

\section{RESULTS}

We evaluated 26 patients with upper limb vascular traumas, $80.8 \%$ of whom were male and $19.2 \%$ of whom were female.

Complementary diagnostic methods could not be used for patients presenting with hemodynamic instability. In one patient with an axillary arterial injury and a huge hematoma, physical examination was not sufficient to establish diagnosis and so DSA was used despite the hemodynamic instability. Another patient with injuries to the left subclavian artery and vein and the internal mammary artery 
and presenting with hemorrhagic shock underwent immediate surgery without any examination or complementary methods.

Overall, $3.8 \%$ of vascular traumas were due to firearm injuries, $3.8 \%$ due to traffic accidents and 92.3\% due to penetrating injuries (Figure 1). The distribution of types of injuries, such as isolated arterial injuries $(76.9 \%)$, isolated vein injuries $(3.8 \%)$, artery-vein injuries $(7.7 \%)$, and artery-veinnerve injuries (11.6\%), is illustrated in Figure 2. Bone

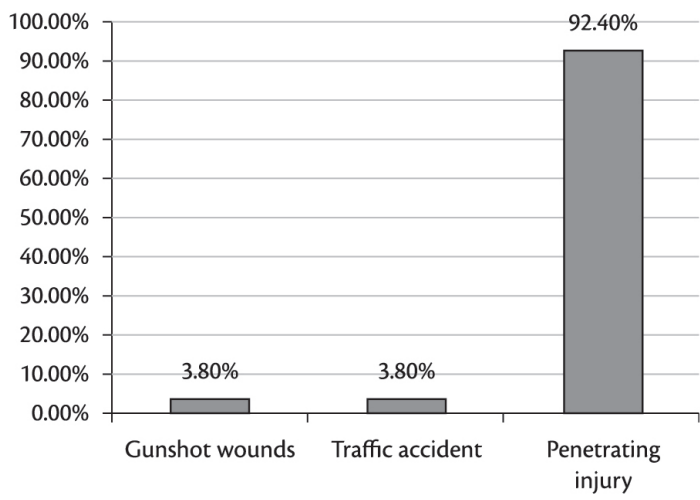

Figure 1. Variety of upper extremity trauma.

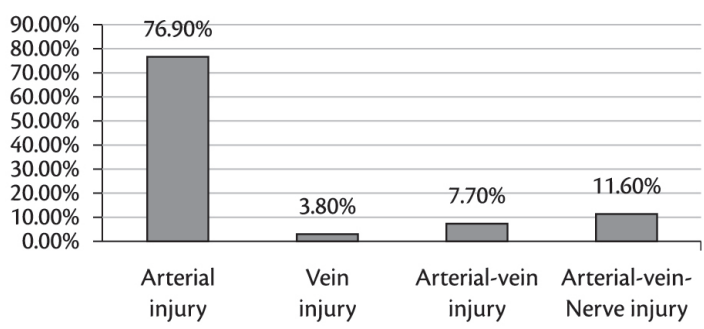

Figure 2. Distribution of damaged tissues.

(4\%), muscle (69.2\%) and tendon injuries (7.7\%) were also evaluated (Table 1).Vascular repair (end to end anastomosis [73.1\%], ligation [7.7\%], use of saphenous vein graft [15.4\%], or use of synthetic graft [3.8\%]) was performed under general anesthesia $(46.2 \%)$ or local anesthesia (53.8\%) (Figure 3).

During the postoperative follow up period, one patient $(3.8 \%)$ had infection due to chylothorax, and was hospitalized for 30 days. He was discharged from the hospital with complete recovery. One patient with subclavian arterial injuries developed upper extremity disability due to atrophy. The remainder of this sample of patients did not have any serious problems related to nerve damage. Thereafter, no further complications related to surgery were observed in any of the patients. The average length of hospital stay was $4.5 \pm 5.6$ days. No amputations were performed on these patients.

Brachial-brachial index (BBI) measurements were $1.05 \pm 0.09$ on the right side and $1.04 \pm 0.08$ on the left side. The average follow-up time was

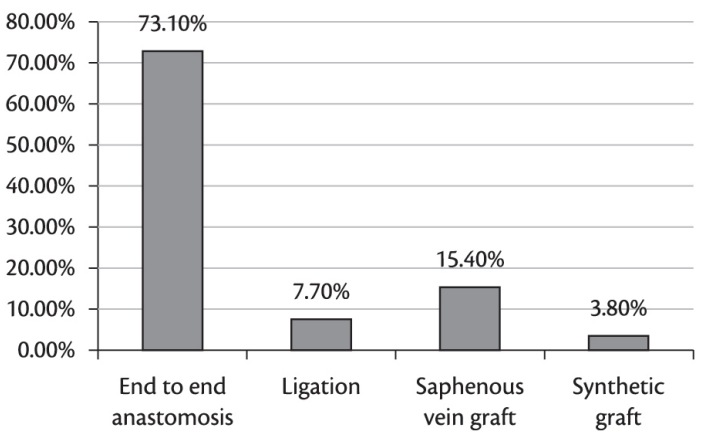

Figure 3. Methods of Surgical treatment.

Table 1. Demographic and clinical features of patients.

\begin{tabular}{|c|c|}
\hline Gender & Male: 21 (80.8\%), Female: 5 (19.2\%) \\
\hline Age (years) & Between 9-56, Mean: 30.27 \\
\hline Type of injury (n) & Penetrating injury: 24, Traffic accident: 1, Gunshot injury: 1 \\
\hline Surgical procedures $(n)$ & Ligation: 2, end to end anastomosis: 19 , graft used: 5 \\
\hline Graft used (n) & Saphenous vein: 4, Synthetic graft: 1 \\
\hline Artery injury(n) & 20 \\
\hline Vein injury (n) & 1 \\
\hline Artery-Vein injury(n) & 2 \\
\hline Artery-Vein-Nerve injury(n) & 3 \\
\hline Tendon injury(n) & 2 \\
\hline Muscle injury(n) & 18 \\
\hline Bone injury(n) & 1 \\
\hline Nerve injury $(n)$ & 5 \\
\hline Postoperative infection (n) & $\mathrm{n}: 1$ \\
\hline Follow-up duration (months) & Minimum: 18, Maximum: 51, Mean: 35.53 \\
\hline
\end{tabular}

n: number of patients. 
$33.5 \pm 10.8$ months. Functional status was evaluated according to the following: neurological assessment, arm movements, muscle atrophy, findings due to arterial occlusion. Evidence of sensory and motor injury was found in patients as follows: numbness (71.4\%), muscle weakness $(26.9 \%)$, sensations of coldness $(15.4 \%)$, paleness $(23 \%)$ after hard work and swelling in the arms (3.9\%). While $71.4 \%$ of the patients had no functional complaints about upper extremity, $7.7 \%$ of the patients were functionally impaired for work.

According to the dUSG utilized during the followup period, vascular occlusion was observed in $15.4 \%$ of the patients. Arterial occlusions were observed in 2 patients with subclavian arterial injury and radial arterial injury (radial artery was treated with endto-end anastomosis). BBI were detected as normal or close to normal in four patients diagnosed with artery occlusion on dUSG. In two patients with subclavian artery occlusion BBI was 0.97 and 0.98 , while two patients with radial artery occlusion had BBI of 1 and 1.1.

\section{DISCUSSION}

Artery injuries are always the easiest upper extremity vascular injuries to diagnose quickly and accurately. Physical examination is the first and the most important tool for diagnosis of upper extremity vascular injuries. Active bleeding, paleness, coldness, inability to find a pulse in an extremity and growing pulsatile masses are major criteria for diagnosis. Diagnosis can be made by dUSG with 99\% sensitivity, and $98 \%$ accuracy. ${ }^{6}$ Routine use of angiography should be discussed. ${ }^{7}$ For subclavian arterial injuries, computed tomography angiography stands out. ${ }^{4}$ Many of the patients in our series were diagnosed with dUSG and DSA was necessary in only one patient, due to axillary arterial injury.

Further discussion is still needed of whether the first approach should be to treat vascular systems or the bone system if there is bone damage in addition to arterial injuries. One of our patients had bone injuries and, as supported by the literature, the orthopedic intervention was performed first. ${ }^{8}$ Shunts can be used in order to avoid increasing tissue ischemia time while orthopedic interventions are being performed. ${ }^{9}$ There are also some authors who support the idea that vascular systems should be treated first, to shorten the duration of ischemia. ${ }^{10,11}$ Our opinion is that if orthopedic intervention is conducted after vascular systems have been treated, the reconstructed vascular system may be jeopardized.
The surgeon's decision on managing artery injuries is very important during the operation. If there is a healthy intima which will not cause stretching to the anastomosis line, then end-to-end anastomosis should be preferred at all times. ${ }^{12}$ If endto-end anastomosis is not possible, vein grafts should be preferred first, due to better patency rate and resistance to infection. ${ }^{13}$ End-to-end anastomosis is the first method of choice for small diameter arteries. For anastomosis of these arteries, single stitches should be used instead of a continuous sewing technique, in order to avoid spasms and tightening that could occur along the anastomosis line.

In our follow-up we found occlusion in one patient who had gunshot injuries and whose radial artery had been anastomosed in an end-to-end fashion. Although an anastomosis line seems suitable in such injuries, vascular damage can occur due to the thermal effect and this reduces the success rate. In such patients, anastomosis has to be performed as distant from the injured area as possible, and, if possible, autogenic grafts should be used. Amputation rarely occurs in upper extremity injuries because of the rich collateral circulation. $^{14}$

Doppler ultrasonography and BBI were used for patient follow-up. With regard to evaluation of lower extremity flow findings, those with an $\mathrm{BBI}<1$ should be accepted as having flow limitation. ${ }^{15}$

In our series we didn't find any difference between the BBI of normal upper extremities and BBI for upper extremities with traumatic vascular occlusion after surgical intervention. The BBI was even found to be 0.97 in a patient with left subclavian occlusion. This is proof that the collateral circulation is of much importance in the upper extremity and the reason why amputation is rarely needed. In our series, no patients with arterial occlusion required amputation. On the other hand, functional deficits related to nerve and vessel damage may develop. This is why long-term follow-up is important in these patients.

In the literature the rate of functional deficits following nerve injuries in upper extremities is $27-44 \%$. $^{3}$ Traumatic nerve damages mostly cause deformations in extremities. ${ }^{7}$ It is still open to debate whether the nerves should be treated primarily or secondarily. ${ }^{11}$ During follow-up, complaints of numbness of an extremity were observed in $71.4 \%$ of patients although artery and vein damage was only seen in $15.4 \%$ of patients. Throughout the follow-up period we observed that although enough blood flow is provided, problems related to loss of the capacity 
to work and inability to use the extremity persist as long as nerve injury remains.

Related venous injuries are often seen intraoperatively. Small venous vessels can be ligated, but larger venous injuries should be reconstructed. Thrombosis occurs in 39-59\% after venous repairs. ${ }^{16}$ We did not observe venous thrombosis in our patients.

In the course of repairing vascular injuries surgeons generally concentrate on arterial damage. It is obvious that attention must first be directed to the arterial injury. However, other concomitant injuries to veins, bones, tendons and nerves should not be ignored, so a multidisciplinary approach is important. This group of young patients should be sent back to their work lives and social lives right away and should be kept under strict surveillance and given help in the form of physical therapy and rehabilitation.

In summary, BBI did not correlate with functional disability in patients who had undergone upper extremity vascular surgery for trauma.

Evaluation of the postoperative outcomes of this small series of patients with penetrating vascular traumas in the upper extremity revealed that $15 \%$ of them suffered occlusion of one artery of the upper extremity. Artery occlusion did not correlate with brachial-brachial Doppler index, probably due to rich collateral circulation, but occlusion was associated with an extremity that was dysfunctional for the purposes of daily work.

\section{REFERENCES}

1. Milas ZL, Dodson TF, Ricketts RR. Pediatric blunt trauma resulting in major arterial injuries. Am Surg. 2004;70:443- 7. PMid:15156954.

2. Kendall $\mathrm{KM}$, Burton $\mathrm{JH}$, Cushing B. Fatal subclavian artery transection from isolated clavicle fracture. J Trauma. 2000;48:316-8. PMid:10697095. http://dx.doi. org/10.1097/00005373-200002000-00022

3. Shalhub S, Starnes BW, Hatsukami TS, Karmy-Jones R, Tran NT. Repair of blunt thoracic outlet arterial injuries: an evolution from open to endovascular approach. J Trauma. 2011,71:114-21. PMid:22071946. http://dx.doi.org/10.1097/TA.0b013e31822cf359

4. Zellweger R, Hess F, Nicol A, Omoshoro-Jones J, Kahn D, Navsaria P. An analysis of 124 surgically managed brachial artery injuries. Am J Surg. 2004;188:240-5. PMid:15450827. http://dx.doi.org/10.1016/j. amjsurg.2004.02.005

5. Bennett JR, Bodenham AR, Berridge JR. Advanced trauma life support: A time for reappraisal. Anaesthesia. 1992;47:798-800.

6. Bynoe RP, Miles WS, Bell RM, Greenwold DR, Sessions G, Haynes JL. Non-invasive diagnosis of vascular trauma by duplex ultrasonography. J Vasc Surg. 1991;14:346-52. http://dx.doi. org/10.1016/0741-5214(91)90087-B

7. Ergünes K, Yilik L, Ozsoyler I, Kestelli M, Ozbek C, Gurbuz A. Traumatic brachial artery injuries. Tex Heart Inst J. 2006;33:31-4. PMid:16572866 PMCid:PMC1413600.
8. McHenry TP, Holcomb JB, Aoki N, Lindsey RW. Fractures with major vascular injuries form gunshot wounds: implications of surgical sequence. J Trauma. 2002;53:717-21. PMid:12394872. http://dx.doi.org/10.1097/00005373-200210000-00016

9. Franz RW, Goodwin RB, Hartman JF, Wright ML. Management of upper extremity arterial injuries at an urban level 1 trauma center. Ann Vasc Surg. 2009;23:8-16 PMid:18640813. http://dx.doi. org/10.1016/j.avsg.2008.04.012

10. Hunt CA, Kingsley JR. Vascular injuries of the upper extremity. South Med J. 2000;93:466-68. PMid:10832942. http:// dx.doi.org/10.1097/00007611-200005000-00004

11. Hardin WD Jr, O'Connell RC, Adinolfi MF, Kerstein MD. Traumatic arterial injuries of the upper extremity: determinants of disability. Am J Surg. 1985;150:266-70. http://dx.doi. org/10.1016/0002-9610(85)90134-5

12. Ekim $\mathrm{H}$, Tuncer $M$. Management of traumatic brachial artery injuries: a report on 49 patients. Ann Saudi Med. 2009;29:1059. PMid:19318753 PMCid:PMC2813640. http://dx.doi. org/10.4103/0256-4947.51797

13. Reynolds RR, McDowell HA, Diethelm AG. The surgical treatment of arterial injuries in the civilian population. Ann Surg. 1979;189:700-8. PMid:453941 PMCid:PMC1397245. http://dx.doi. org/10.1097/00000658-197906000-00005

14. McCroskey BL, Moore EE, Pearce WH, Moore FA, Cota R, Sawyer JD. Traumatic injuries of the brachial artery. Am J Surg.1988;156:553-5. http://dx.doi.org/10.1016/S0002-9610(88)80551-8

15. Hafez HM, Woolgar J, Robbs JV. Lower extremity arterial injury: results of 550 cases and review of risk factors associated with limb loss. J Vasc Surg. 2001;33:1212-9. PMid:11389420. http://dx.doi. org/10.1067/mva.2001.113982

16. Timberlake GA, O'Connell RC, Kerstein MD. Venous injury: to repair or ligate, the dilemma. J Vasc Surg. 1986;4:553-8. PMid:3783830.

Correspondence Erdal Simsek Ceyhun Atif Kansu street 166/4 Cevizlidere, Balgat/Ankara, Turkey Tel.: +905323280217 E-mail: erdaldr@yahoo.com

Author information ES is a cardiovascular surgeon at Turkiye Yuksek Ihtisas Training and Research Hospital. KK is a cardiovascular surgeon at Diskapi Yildirim Beyazit Training and Research hospital.

II is a cardiovascular surgeon at Tokat Gaziosmanpaşa University. ATU is a cardiovascular surgeon at Turkiye Yuksek Ihtisas Training and Research Hospital.

Author contributions Conception and design: ES, KK, II Analysis and interpretation: ES, ATU Data collection: KK, II Writing the article: ES Critical revision of the article: ATU Final approval of the article*: ES, KK, II, ATU Statistical analysis: ATU Overall responsibility: ES

* All authors have read and approved of the final version of the article submitted to I Vasc Bras. 